\title{
OPTIMASI KANDUNGAN GIZI UNTUK MENU HARIAN MENGGUNAKAN FUZZY INTEGER PROGRAMMING
}

\author{
Lailil Muflikhah ${ }^{1}$, Galang Gilang Ramadhan ${ }^{2}$, Marji $^{3}$ \\ 1,2,3 Fakultas Ilmu Komputer, Universitas Brawijaya, Malang \\ e-mail: ${ }^{1}$ lailil@ub.ac.id \\ (Naskah masuk: 20 Mei 2016, diterima untuk diterbitkan: 20 Juni 2016)
}

\begin{abstract}
Abstrak
Tujuan utama dari optimasi kandungan gizi adalah membantu pengguna menemukan daftar menu harian termurah berdasarkan kebutuhan gizinya serta biaya yang ditetapkan. Permasalahan ini cukup menantang karena banyak melibatkan data yang sifatnya tak pasti atau buram sehingga tidak dapat diselesaikan dengan metode optimasi dasar seperti Linear Programming. Fuzzy Linear Programming adalah solusi lain yang dapat digunakan. Namun oleh karena sifatnya yang linear, metode ini menimbulkan efek di mana kombinasi makanan yang dihasilkan bisa jadi tidak enak untuk dikonsumsi (unpalatable). Fuzzy Integer Programming (FIP), yang merupakan pengembangan dari Integer Programming, menerapkan batasan-batasan yang lebih ketat pada model matematika dari permasalahan. Dengan menggunakan metode yang mengkonversi model FIP menjadi model Multiple Objective Integer Programming Problem (MOIPP), Integer Programming yang melibatkan data tak pasti dapat dipecahkan dengan mudah. Pengujian dengan membandingkan hasil dari metode ini dengan sebuah hasil metode apriori optimal. Metode ini diperoleh dari pembangkitan seluruh kombinasi yang mungkin sehingga menunjukkan bahwa metode ini mampu menemukan variasi menu optimal dengan tingkat optimalitas $100 \%$ dalam berbagai kondisi keburaman data. Dengan demikian, Fuzzy Integer Programming dapat dikatakan sebagai solusi yang dapat diandalkan untuk menyelesaikan permasalahan optimasi kandungan gizi menu harian.
\end{abstract}

Kata Kunci: Kandungan gizi, Fuzzy Integer Programming, Menu Harian, Optimasi

\begin{abstract}
The main purpose of nurient optimization is to help user find the cheapest of daily menu, according to their nutrient needs and specified cost. This problem is quite challenging due to many uncertanty data are involved so that it can't be solved by using basic optimization method such as Linear Programming. Fuzzy Linear Programming is another solution that can be used. How ever, because of its characteristic is linear, this method has an effect that can produce an unpalatable food combination. Fuzzy Integer Programming (FIP) which extends Integer Programming method, apply more strictly constraints to the problem's mathematical model. By using a method that converts an FIP model into Multiple Objective Integer Programming Problem (MOIPP) model, Integer Programming with fuzzy data is solvable easily. A test result is compared to an a priori optimal result. It is obtained from an exhaustive combination generation so that shows that this method is capable to find the optimal menu within various data fuzziness with optimality of 100\%. Hence, Fuzzy Integer Programming can be considered as a reliable solution to solve optimization of daily menu nutrient.
\end{abstract}

Keywords: Nutrient, Fuzzy Integer Programming, Daily Menu, Optimization

\section{PENDAHULUAN}

Seiring dengan semakin meningkatnya harga bahan-bahan pangan, masyarakat dituntut untuk semakin pandai dalam menyiasati menu harian mereka. Namun karena batasan biaya, seringkali kandungan gizi pada menu harian dikesampingkan. Padahal, dengan melakukan variasi pada susunan menu harian yang ada, akan sangat mungkin untuk mendapatkan susunan menu dengan kandungan gizi yang cukup dan biaya yang lebih terjangkau. Masalahnya adalah, kebanyakan masyarakat awam tidak memiliki waktu dan sumber daya yang cukup untuk mempertimbangkan variasi-variasi tersebut.
Tujuan utama optimasi kandungan gizi menu harian adalah untuk membantu pengguna menemukan variasi termurah dari daftar menu harian mereka, berdasarkan kebutuhan gizinya serta batasan biaya yang ditetapkan. Permasalahan ini cukup menantang karena banyak melibatkan data yang sifatnya tak pasti atau buram sehingga tidak dapat diselesaikan dengan metode optimasi dasar seperti Linear Programming. Untuk dapat mengakomodasi keburaman data tersebut, dapat dipergunakan metode Fuzzy Linear Programming. Namun dikarenakan sifatnya yang linear, metode ini juga memiliki kekurangan di mana kombinasi makanan yang dihasilkan bisa jadi tidak enak 
untuk dikonsumsi (unpalatable). Efek ini telah coba diminimalisasi pada penelitian yang dilakukan oleh Prasetyo (2010) dengan memanfaatkan Ukuran Rumah Tangga (URT), yakni ukuran normal konsumsi bahan makanan, sebagai batasan. Namun, solusi ini dirasa masih kurang efektif mengingat URT tidak menggambarkan proporsi suatu bahan relatif terhadap bahan lainnya pada suatu menu.

Fuzzy Integer Programming (FIP) adalah metode lain yang dapat diterapkan pada kasus optimasi kandungan gizi menu harian. Metode yang merupakan pengembangan dari Integer Programming ini memiliki kelebihan di mana metode ini menerapkan batasan-batasan yang lebih ketat pada model matematika dari permasalahan yang akan diselesaikan. Metode ini juga dapat mengakomodasi data-data buram dengan cara mengonversi model permasalahan yang akan diselesaikan menjadi model Multiple Objective Integer Programming Problem (MOIPP) (Dash \& Dash, 2012). FIP telah diterapkan oleh Oruç, et al. (2012) sebagai algoritma perencanaan menu bagi pekerja. Pada penelitian tersebut, FIP digunakan untuk merencanakan menu selama 20 hari dari kerangka menu yang telah ditentukan dengan memperhatikan batasan kebutuhan gizi pekerja. Namun demikian, model non-selective menu planning (pengguna tidak memilih sendiri menunya) seperti yang digunakan oleh Oruç, et al. (2012) memiliki kelemahan dari sisi fleksibilitas pengguna.

Pada penelitian ini, akan digunakan pendekatan yang hampir sama dengan yang digunakan oleh Oruç, et al. (2012). Akan tetapi, model perencanaan menu yang akan digunakan adalah selective menu planning. Artinya, sistem tidak memilihkan menu untuk pengguna, tetapi pengguna sendiri yang memilih menu-menu yang ingin dioptimasi. Perbedaan lain antara penelitian ini dengan penelitian oleh Oruç, et al. (2012) terletak pada obyek yang ingin dioptimasi. Berbeda dengan pendekatan Oruç, et al. (2012) yang pada dasarnya adalah optimasi di tingkat bahan, penelitian ini akan melakukan optimasi di tingkat menu. Sebuah menu dapat terdiri dari beberapa bahan, dan bahan-bahan dalam sebuah menu independen terhadap bahan-bahan dari menu lain. Setelah pengguna memilih menu-menu yang ingin dioptimasi, FIP akan melakukan optimasi pada jumlah penyajian tiap menu. Dengan melakukan optimasi pada tingkat menu dan bukan pada tingkat bahan, komposisi bahan akan tetap proporsional terhadap resep aslinya. Proporsionalitas komposisi bahan inilah yang dapat menjaga makanan tetap palatable.

\subsection{Menu harian}

Menu harian adalah komposisi makanan yang dikonsumsi seseorang atau sebuah keluarga dalam satu hari. Idealnya, kandungan gizi dalam menu harian harus mencukupi kebutuhan gizi orang atau keluarga tersebut. Di Indonesia dikenal slogan "4 sehat 5 sempurna" yang dapat digunakan masyarakat awam sebagai panduan untuk menyusun menu harian yang seimbang dan berkecukupan. Komposisi nasi, lauk, sayur, buah dan susu dalam menu "4 sehat 5 sempurna" diperkirakan dapat memenuhi kebutuhan energi, protein, lemak, vitamin serta mineral seseorang secara umum. Pada Tabel 1 diberikan contoh menu harian untuk 5 hari.

Tabel 1 Contoh menu harian (Karyadi \& Muhilal, 1985)

\begin{tabular}{llllll}
\hline Hari Ke- & Makanan Pokok & Lauk & Sayur & Buah & Selingan \\
\hline 1 & Nasi & Tempe Goreng & Lodeh & Pepaya & Singkong Goreng \\
2 & Nasi & Pepes Ikan & Lalap & Pisang & Ubi Rebus \\
3 & Nasi & Ikan Asin & Sayur Bayam & Jeruk & Jagung Rebus \\
4 & Nasi & Tahu Goreng & Gado-Gado & Pisang & Singkong Rebus \\
5 & Nasi & Telur Rebus & Tumis Kangkung & Pepaya & Kue Dari Singkong \\
\hline
\end{tabular}

\subsection{Fuzzy Number}

Sebuah bilangan buram atau fuzzy number adalah kuantitas yang nilainya tidak tepat atau tidak pasti (Joshi, 2008). Fuzzy number tidak seperti bilangan biasa yang hanya merujuk pada satu nilai, melainkan merujuk pada sekumpulan nilai-nilai yang mungkin. Tiap nilai yang mungkin memiliki bobot tersendiri yang disebut sebagai fungsi keanggotaan atau membership function, antara 0 dan 1. Salah satu tipe fuzzy number adalah Triangular Fuzzy Number, yang dinotasikan sebagai $\mathbb{\square}=(\mathbb{\square}, \mathbb{\square}, \mathbb{\square})$ dan memiliki fungsi keanggotaan (Fullér, 1991):

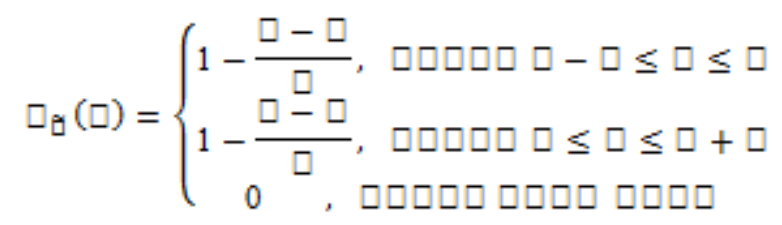

Gambar 1 merupakan grafik fungsi keanggotaan dari sebuah Triangular Fuzzy Number.।

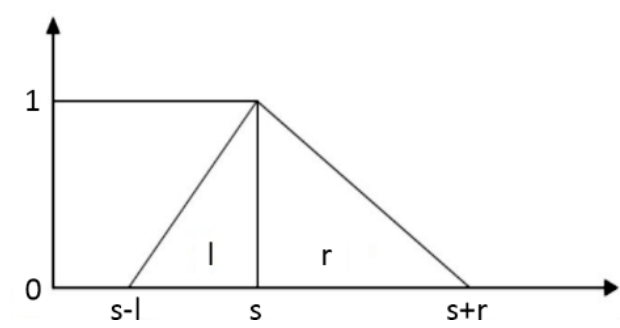

Gambar 1 Triangular Fuzzy Number (Roseline \& Amirtharaj, 2012)

Jika $A=\left(s_{1}, l_{1}, r_{1}\right)$ dan $\hat{B}=\left(s_{2}, l_{2}, r_{2}\right)$ adalah dua buah Triangular Fuzzy Number, maka berlaku 
operasi-operasi berikut (Roseline \& Amirtharaj, 2012):

- $A+B=\left(s_{1}, l_{1}, x_{1}\right)+\left(s_{2}, l_{2}, x_{2}\right)$

$=\left(s_{1}+s_{2}, l_{1}+l_{2}, x_{1}+r_{2}\right)$

- $\quad A-B=\left(s_{1}, l_{1}, x_{1}\right)-\left(s_{2}, l_{2}, r_{2}\right)$

$=\left(s_{1}-s_{2}, l_{1}-l_{2}, r_{1}-r_{2}\right)$

- $\quad x>0, A x=\left(s_{1} x_{v} l_{1} x, r_{1} x\right)$

$x<0, A x=\left(r_{1} x_{v} l_{1} x_{v} s_{1} x\right)$

- $A \leq B$ jika dan hanya jika $M A X(A, B)=B$

Sehingga untuk setiap Triangular Fuzzy

Number $A=\left(s_{1}, l_{1}, r_{1}\right)$ dan $B=\left(s_{2}, l_{2}, r_{2}\right)$,

$A \leq B$ jika dan hanya jika :

1) $s_{1} \leq s_{2}$

2) $s_{1}-l_{1} \leq s_{2}-l_{2}$

3) $s_{1}+r_{1} \leq s_{2}+l_{2}$

\subsection{Integer Programming}

Integer Programming (IP) adalah Linear Programming dengan tambahan batasan yang mengharuskan beberapa atau semua variabel ada dalam bentuk integer (Bosch \& Trick, 2014). Integer Programming diselesaikan dengan terlebih dahulu melakukan relaksasi pada permasalahan. Relaksasi dari sebuah permasalahan Integer Programming adalah sebuah permasalahan baru sedemikian hingga :

a) Setiap solusi bagi IP bersesuaian dengan sebuah solusi feasible bagi masalah hasil relaksasi.

b) Setiap solusi bagi IP memiliki nilai fungsi objektif lebih besar atau sama dengan solusi yang bersesuaian pada masalah hasil relaksasi.

Setelah dilakukan relaksasi, permasalahan akan diselesaikan secara branch-and-bound sebagai berikut:

\section{- Langkah 0 (inisiasi)}

Tetapkan nilai fungsi tujuan incumbent $v=\infty$ (untuk mengasumsikan kondisi awal di mana belum ada solusi integer yang memenuhi). Tetapkan penghitung node aktif $k=1$ dan tetapkan permasalahan awal sebagai node "aktif". Lanjutkan ke Langkah 1.

\section{- Langkah 1}

Jika $k=0$ (tidak ada node aktif), berhenti. Solusi incumbent adalah solusi optimal. Jika tidak ada solusi incumbent, misal $v=\infty$, maka permasalahan ini tidak memiliki solusi integer. Jika $k \geq 1$ (masih ada node aktif), lanjutkan ke Langkah 2.

\section{- Langkah 2}

Pilih salah satu node aktif dan namai sebagai current node. Selesaikan permasalahan hasil relaksasi dari current node, dan tandai current node sebagai inaktif. Jika tidak ada solusi feasible, lanjutkan ke Langkah 3. Jika solusi dari current node memiliki nilai fungsi tujuan $z^{*} \geq v$, lanjutkan ke Langkah 4. Jika solusi semuanya integer dan $z^{*}<v$, lanjutkan ke Langkah 5 . Selain itu, lanjutkan ke Langkah 6.

\section{- Langkah 3}

Fathomed by Infeasibility. Kurangi $k$ dengan 1 dan kembali ke Langkah 1.

\section{- Langkah 4}

Fathomed by Bound. Kurangi $k$ dengan 1 dan kembali ke Langkah 1.

\section{- Langkah 5}

Fathomed by Integrality. Ganti solusi incumbent dengan solusi current node. Tetapkan $v=z^{*}$, kurangi $k$ dengan 1 dan kembali ke Langkah 1.

\section{- Langkah 6}

Buat cabang pada current node. Pilih variabel yang bernilai fraksional dari solusi permasalahan hasil relaksasi bagi current node. Namai variabel ini sebagai $x_{g}$ dan namai nilai solusi optimalnya sebagai $f$. Buat dua node aktif baru pada current node: satu dengan menambahkan batasan $x_{g} \leq\lfloor f\rfloor$ dan yang lain dengan menambahkan batasan $x_{s} \geq\lceil f\rceil$. Tambahkan 1 pada $k$ (2 node aktif baru minus 1 pencabangan pada current node) dan kembali ke Langkah 1.

\subsection{Konversi FIPP ke MOIPP}

Anggap terdapat FIPP (Fuzzy Integer Programming Problem) dengan koefisien fungsi tujuan dan koefisien batasan-batasannya berupa fuzzy number, atau dapat dituliskan sebagai :

$$
\mathbb{\square \square} \sum_{\square=1}^{\square} \mathbb{\square}_{\square} \mathbb{\square}_{\square}
$$

Sedemikian hingga :

$$
\begin{aligned}
& \sum_{\square \geq 0}\left(\square_{\square \square}, \square_{\square \square}, \square_{\square \square}\right) \square_{\square \square} \leq\left(\square_{\square}, \square_{\square}, \square_{\square}\right)(2 \\
& 0 \leq \mathbb{\square} \leq \mathbb{\square}_{v} 0 \leq \mathbb{\square} \leq \mathbb{\square}
\end{aligned}
$$

Permasalahan tersebut dapat dikonversi ke bentuk MOIPP (Multiple Objective Integer Programming Problem) sebagai (Dash \& Dash, 2012):

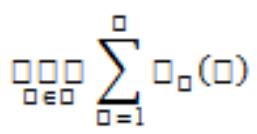




$$
\begin{aligned}
& \sum_{\square=1}^{\square} \mathbb{\square}_{\square \square} \mathbb{\square}_{\square} \leq \mathbb{\square}_{\square} \\
& \sum_{\square=1}^{\square}\left(\mathbb{Q}_{\square \square}-\mathbb{Q}_{\square \square}\right) \square_{\square} \leq \mathbb{\square}_{\square}-\mathbb{\square}_{\square} \\
& \sum_{\square=1}^{\square}\left(\mathbb{Q}_{\square \square}+\mathbb{Q}_{\square \square}\right) \mathbb{\square}_{\square} \leq \mathbb{\square}_{\square}+\mathbb{\square}_{\square}
\end{aligned}
$$

\section{CONTOH PERMASALAHAN}

Misalkan daftar menu harian yang akan dioptimasi berisi menu-menu: "Soto Ayam", "Nasi" dan "Jus Alpokat". Data dari ketiga menu tersebut dapat dilihat pada Lampiran A.

\subsection{Perhitungan nutrisi menu}

Pada tahap ini, tiap menu akan dinormalisasi menjadi 1 porsi terlebih dahulu. Misalnya menu Soto Ayam adalah untuk 4 porsi, maka untuk tiap porsinya terdiri dari:

- Ayam :

$1 / 4 \times(150,10,20)=(37.5,2.5,5)$

- $\mathrm{Kol}$ :

$1 / 4 \times(200,50,50)=(50,12.5,12.5)$

- Bihun :

$1 / 4 \times(50,5,5)=(12.5,1.25,1.25)$

- Telur :

$1 / 4 \times(90,50,10)=(22.5,12.5,2.5)$

- Tomat :

$1 / 4 \times(200,5,10)=(50,1.25,2.5)$

Selanjutnya, dilakukan perhitungan kandungan gizi untuk masing-masing bahan dari tiap menu dan menjumlahkannya menjadi kandungan gizi menu. Sebagai contoh, dari basis data didapatkan kandungan energi ayam per 100 gram adalah 302 $\mathrm{Kcal}$, maka untuk mencari nilai energi (dalam Kcal) bahan ayam dari menu Soto Ayam perhitungannya adalah sebagai berikut:

$$
\frac{1}{100} \times 302 \times(37.5,2.5,5)=(113.25,7.55,15.1)
$$

Jika diasumsikan nutrien yang diikutsertakan adalah energi, protein, lemak, vitamin A, vitamin $\mathrm{B}$, dan vitamin $\mathrm{C}$, maka dengan cara yang sama didapatkan data kandungan gizi tiap menu seperti pada Lampiran B.

\subsection{Pembentukan persamaan FIPP}

Tahap pertama pembentukan persamaan FIPP adalah pembentukan persamaan batasan. Misalkan terdapat Menu $M 1$ dan $M 2$ dengan porsi penyajian normal masing-masing $(1,1 / 2,1 / 4)$ dan $(1,1 / 4)$, maka akan terbentuk 2 persamaan:

$$
\text { 1) } \square_{11} \square 11+\square_{12} \square 12+\square_{13} \square 13+\square_{14} \square 21+
$$

$$
\square_{21} \square 11+\square_{22} \square 12+\mathbb{\square}_{23} \square 13+\square_{24} \square 21+
$$$$
\text { 2) } \mathbb{\square}_{25} \square 22 \geq \mathbb{\square}_{2}
$$

Di mana $M 11=1$ porsi $M 1, M 12=1 / 2$ porsi $M 1, M 13=1 / 4$ porsi $M 1, M 21=1$ porsi $M 2$ dan $M 22=1 / 4$ porsi $M 2 . b_{1}$ dan $b_{2}$ adalah angka batasan nutrien atau dapat dikatakan kebutuhan gizi subjek. Diasumsikan kebutuhan gizi subjek adalah sebagai berikut:

- $\quad$ Energi $=1000 \mathrm{Kcal}$

- Protein $=25 \mathrm{~g} / \mathrm{d}$

- Vitamin $\mathrm{A}=450 \mu \mathrm{g} / \mathrm{d}$

- Vitamin $\mathrm{B}=0.5 \mathrm{mg} / \mathrm{d}$

- Vitamin $\mathrm{C}=45 \mathrm{mg} / \mathrm{d}$

Untuk membuat batasan menjadi lebih fleksibel, batasan akan diubah menjadi sebuah triangular fuzzy number, dengan nilai $l$ dan $r$ diatur oleh parameter yang disebut sebagai 'reference fuzziness'. Parameter ini menentukan berapa persen nilai left spread (l) dan/atau right spread $(r)$ dari nilai pastinya $(s)$. Pada contoh ini, parameter reference tolerance akan diberi nilai $15 \%$. Maka, untuk batasan energi dengan angka 1000 akan menghasilkan:

- Left spread : $15 \% \times 1000=150$

- Right spread : $15 \% \times 1000=150$

- Triangular Fuzzy number $(s, l, r)$ : $(1000,150,150)$

Dengan cara yang sama, batasan-batasan untuk nutrien lain dapat dibentuk dan akan menghasilkan persamaan-persamaan baru. Selain batasan-batasan tersebut, diperlukan lagi beberapa batasan tambahan. Batasan tambahan pertama adalah batasan untuk menjaga total harga agar tidak melebihi anggaran:

$$
\begin{aligned}
& (16000,1000,1000) \square 11+ \\
& (8000,500,500) \square 12+(4000,250,250) \square 13+ \\
& (2000,125,125) \square 14+(4000,500,500) \square 21+ \\
& (6000,500,500) \square 31+ \\
& (3000,250,250) \square 32 \leq(30000,0,0)
\end{aligned}
$$

Beberapa batasan juga diperlukan untuk memastikan setiap menu dalam menu set yang dipilih disajikan tepat 1 kali:

$$
\begin{aligned}
& \text { 1) } \square 11+\square 12+\square 13+\square 14=1 \\
& \text { 2) } \square 21=1
\end{aligned}
$$




\section{3) $\square 31+\square 32=1$}

Batasan terakhir yang dibutuhkan adalah apa yang disebut sebagai 'integrality constraints'. Batasan ini menjaga agar tiap variabel tujuan bernilai lebih dari atau sama dengan nol dan merupakan sebuah bilangan integer:

$\square 11, \square 12, \square 13, \square 14, \square 21, \square 31, \square 32 \geq 0$,

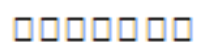

Setelah semua persamaan batasan tersebut terbentuk, tahap terakhir pembentukan persamaan FIPP adalah membentuk persamaan fungsi tujuan.

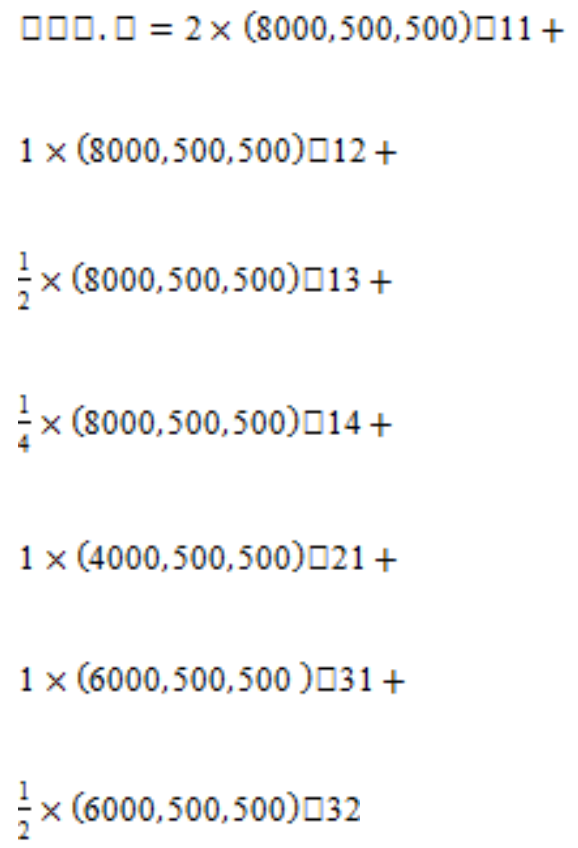

Atau

$\square \square \square . \square=(16000,1000,1000) \square 11+$
$(8000,500,500) \square 12+$
$(4000,250,250) \square 13+$
$(2000,125,125) \square 14+$
$(4000,500,500) \square 21+$
$(6000,500,500) \square 31+$
$(3000,250,250) \square 32$

\subsection{Konversi FIPP ke MOIPP}

FIPP yang telah terbentuk selanjutnya akan dikonversi ke bentuk MOIPP agar dapat diselesaikan dengan menggunakan metode Integer Programming biasa. Berdasarkan Persamaan (3), fungsi tujuan pada Persamaan (5) dapat dikonversi menjadi :

$$
\begin{aligned}
& \square \square \square . \square=18000 \square 11+9000 \square 12+ \\
& 4500 \square 13+2250 \square 14+5000 \square 21+ \\
& 7000 \square 31+3500 \square 32
\end{aligned}
$$

Konversi juga dilakukan pada batasan-batasan FIPP. Berdasarkan Persamaan (4a) hingga Persamaan (4c), sebuah persamaan batasan yang melibatkan fuzzy number dalam FIPP akan dikonversi menjadi 3 buah persamaan batasan.

\subsection{Pemecahan dengan integer programming}

Setelah fungsi tujuan dan batasan-batasan dikonversi, maka permasalahan tersebut dapat dipecahkan dengan metode Integer Programming biasa. Permasalahan Integer Programming dengan fungsi tujuan Persamaan (6) dan batasan-batasan pada Lampiran D menghasilkan solusi:

$(\square 11, \square 12, \square 13, \square 14, \square 21, \square 31, \square 32)=$

$$
(0,0,0,1,1,1,0)
$$

Solusi dari Integer Programming ini juga sekaligus merupakan solusi akhir dari Fuzzy Integer Programming. Dari solusi tersebut diketahui bahwa menu-menu yang dipilih adalah $M 14, M 21$ dan M31. Artinya, kombinasi menu optimal menurut sistem adalah sebagai berikut :

- $\quad$ Soto Ayam : $1 / 4$ porsi

- $\quad$ Nasi : 1 porsi

- Jus Alpokat : 1 porsi

\section{DATA}

\subsection{Data kandungan gizi bahan makanan}

Data kandungan gizi bahan makanan didapat dari basis data United States Department of Agriculture (USDA) (U.S. Department of Agriculture, 2014).. Data dapat diakses secara bebas pada alamat http://ndb.nal.usda.gov/ndlø5.)

\subsection{Data satuan bahan makanan}

Data satuan bahan makanan adalah data yang berisi satuan-satuan atau unit-unit dari sebuah bahan makanan. Yang dimaksud dengan satuan di 
sini misalnya "Sendok Makan", "Sendok Teh" dan sebagainya. Data ini didapatkan dari sumber yang sama serta dengan metode pengumpulan yang sama dengan data kandungan gizi bahan makanan.

\subsection{Data menu}

Data ini menjelaskan bahan-bahan pembuat, takaran masing-masing bahan, porsi, porsi penyajian standar, serta harga dari sebuah menu makanan. Situs berbagi resep cookpad.com/id dijadikan sebagai rujukan dalam penyusunan resep-resep yang akan dijadikan data. Harga menu makanan akan dihitung berdasarkan jumlah harga bahan-bahan pembuatnya. Data mengenai porsi penyajian standar diperkirakan berdasarkan kuantitas konsumsi wajar seseorang terhadap suatu menu. Data-data ini kemudian akan dikonsultasikan dengan pakar gizi untuk mendapatkan validasi bahwa data-data tersebut valid dan layak digunakan sebagai data penelitian.

\subsection{Data menu set}

Data ini digunakan untuk menguji optimalitas algoritma. Data berisi susunan menu-menu yang mungkin dikonsumsi seseorang dalam satu hari. Sebelum digunakan sebagai data pengujian, data menu set ini akan terlebih dahulu dikonsultasikan dengan pakar gizi untuk mendapatkan validasi bahwa kasus-kasus yang direpresentasikan dalam data memang mungkin terjadi dan data dianggap layak dijadikan sebagai data uji.

\subsection{Data acuan kecukupan gizi}

Data ini digunakan sebagai acuan untuk menentukan kebutuhan gizi individu berdasarkan usia, jenis kelamin, berat badan, tinggi badan serta tingkat aktivitasnya. Acuan yang digunakan dalam penelitian ini adalah data DRI (Dietary Reference Intakes).

\section{STRATEGI PENGUJIAN}

\subsection{Ukuran kualitas algoritma}

Ukuran yang digunakan untuk menentukan kualitas algoritma FIP dalam menyelesaikan permasalahan optimasi kandungan gizi menu harian adalah tingkat optimalitasnya. Uji optimalitas dilakukan dengan membandingkan kombinasi hasil optimasi algoritma FIP dengan semua kemungkinan kombinasi yang dibangkitkan secara menyeluruh (exhaustive). Proses uji optimalitas dapat digambarkan dalam diagram pada Gambar 2.

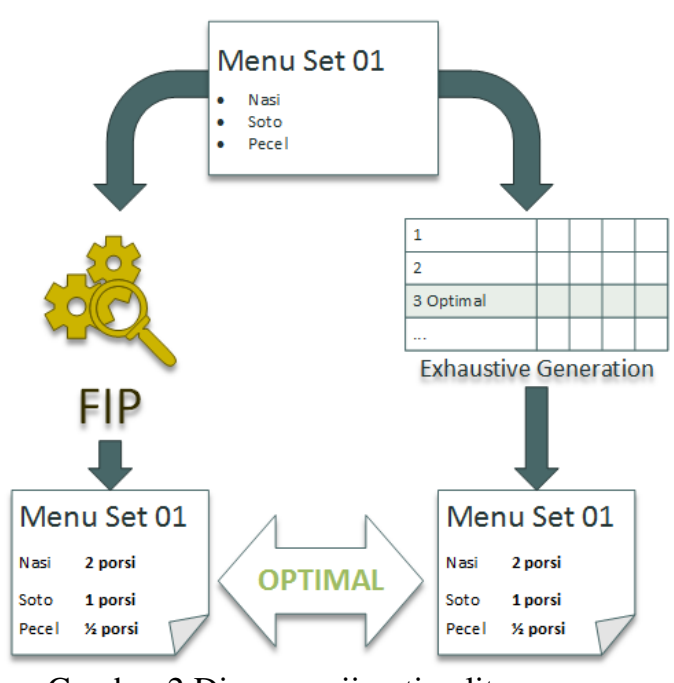

Gambar 2 Diagram uji optimalitas

\subsection{Pembangkitan exhaustive}

Untuk menguji apakah hasil optimasi dengan algoritma FIP memang merupakan kombinasi terbaik dari seluruh kombinasi yang mungkin, diperlukan sebuah strategi pembangkitan seluruh kemungkinan kombinasi. Strategi yang disebut sebagai pembangkitan exhaustive ini akan terlebih dahulu mendaftar seluruh kemungkinan kombinasi dari permasalahan yang sedang diselesaikan. Selanjutnya, setiap kombinasi akan dihitung nilai gizi dan harganya .Kombinasi-kombinasi yang tidak memenuhi kriteria (infeasible) kemudian disingkirkan dari daftar. Setelah daftar hanya berisi kombinasi yang memenuhi kebutuhan gizi (feasible), dapat diketahui kombinasi optimal, yakni kombinasi yang memiliki harga paling murah. Jika kombinasi ini sama dengan kombinasi yang diberikan oleh FIP, maka untuk kasus ini algoritma FIP dikatakan telah optimal.

\subsection{Parameter-parameter yang akan diuji}

Pengujian ini digunakan untuk mengetahui optimalitas algoritma dalam kasus nyata yang bertujuan untuk mengetahui pengaruh parameterparameter yang dixuji terhadap optimalitas algoritma. Data yang digunakan pada pengujian ini adalah data asli yang merupakan data yang dimasukkan oleh pengguna tanpa dilakukan override. Artinya, parameter menu food weights fuzziness dan parameter menu price fuzziness diset sebagai 'bebas'. Data-data ini kemudian akan diuji dengan parameter reference fuzziness yang diberi nilai mulai dari $0 \%$ hingga $10 \%$ dengan kelipatan $1 \%$ untuk tiap skenario.

Tabel 2 Parameter dari skenario 


\begin{tabular}{llll}
\hline Skenario & $\begin{array}{l}\text { Keburaman } \\
\text { Berat Bahan } \\
\text { Penyusun }\end{array}$ & $\begin{array}{l}\text { Keburaman } \\
\text { Harga Menu } \\
\text { (\%) }\end{array}$ & $\begin{array}{l}\text { Keburaman } \\
\text { Batasan (\%) }\end{array}$ \\
\hline D.0 & Bebas & Bebas & 0 \\
D.1 & Bebas & Bebas & 1 \\
D.2 & Bebas & Bebas & 2 \\
D.3 & Bebas & Bebas & 3 \\
D.4 & Bebas & Bebas & 4 \\
D.5 & Bebas & Bebas & 5 \\
D.6 & Bebas & Bebas & 6 \\
D.7 & Bebas & Bebas & 7 \\
D.8 & Bebas & Bebas & 8 \\
D.9 & Bebas & Bebas & 9 \\
D.10 & Bebas & Bebas & 10 \\
\hline
\end{tabular}

\section{HASIL PENGUJIAN}

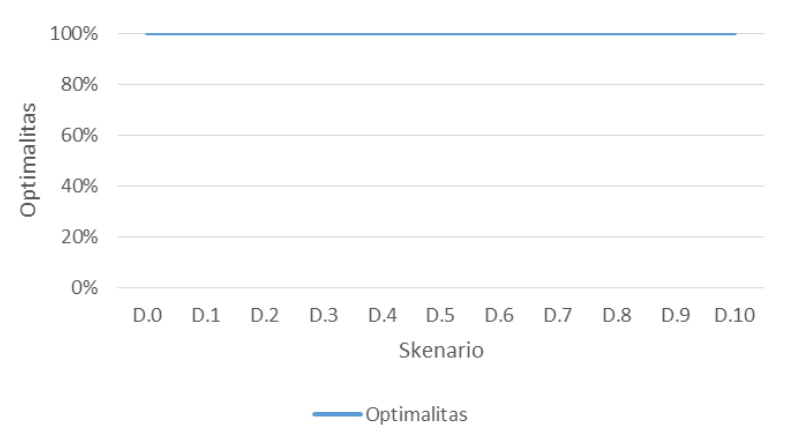

Gambar 3 Grafik optimalitas

Grafik optimalitas pada Gambar 3 menunjukkan bahwa algoritma dapat diterapkan untuk kasus nyata dengan optimalitas $100 \%$. Seperti digambarkan dalam grafik tersebut, pada kasus nyata di mana data berat bahan penyusun menu, data harga menu serta data batasan gizi memiliki keburaman yang bervariasi, algoritma tetap dapat menemukan kombinasi paling optimal jika memang masalah tersebut memiliki solusi.

Untuk penerapan pada kasus nyata dengan keburaman batasan sebesar $10 \%$ (skenario D.10), didapatkan persentase capaian dengan rincian seperti yang tersaji pada Tabel dan dapat digambarkan dalam bentuk grafik pada Gambar . Dari grafik tersebut terlihat bahwa solusi-solusi yang dihasilkan oleh algoritma memiliki rata-rata nilai pemenuhan nutrisi di atas $100 \%$. Artinya, kebutuhan nutrisi subjek dapat terpenuhi dengan baik. Dari sisi harga, terlihat pula bahwa solusisolusi yang diberikan algoritma memiliki harga berkisar antara $46.59 \%$ hingga $66.74 \%$ dari anggaran yang diberikan. Dengan demikian, dapat dikatakan bahwa solusi-solusi yang diberikan algoritma memiliki harga yang terjangkau.

Tabel 3 Persentase capaian penerapan pada kasus nyata

\begin{tabular}{llll}
\hline & Min. & Mid. & Maks. \\
\hline Energi & $105.57 \%$ & $108.42 \%$ & $111.03 \%$ \\
Protein & $159.81 \%$ & $163.26 \%$ & $167.45 \%$ \\
Vitamin A & $120.94 \%$ & $124.59 \%$ & $129.41 \%$ \\
Vitamin B1 & $157.21 \%$ & $159.64 \%$ & $162.97 \%$ \\
Vitamin C & $324.39 \%$ & $330.62 \%$ & $339.65 \%$ \\
Harga & $46.59 \%$ & $56.75 \%$ & $66.74 \%$ \\
\hline
\end{tabular}

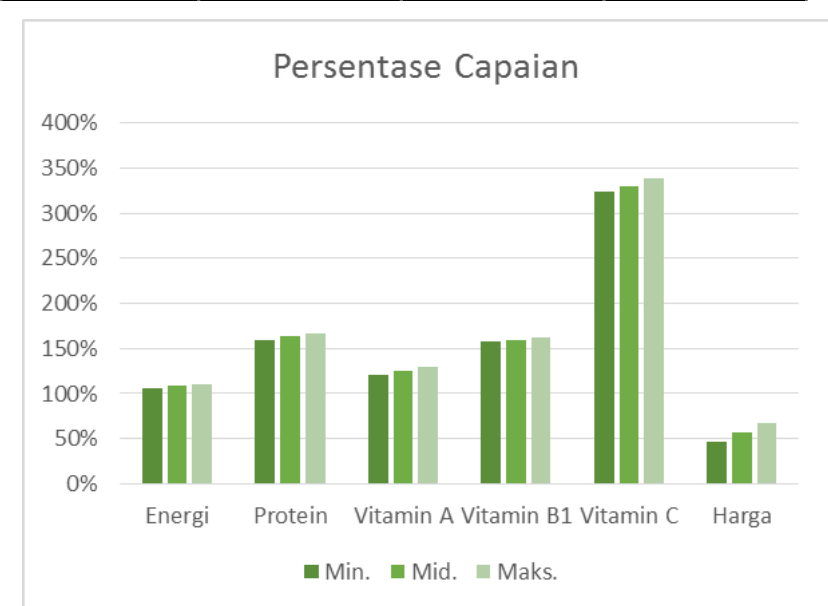

Gambar 4 Grafik persentase capaian penerapan pada kasus nyata

\section{KESIMPULAN}

Berdasarkan hasil penelitian dan analisa yang telah dilakukan pada hasil penelitian, didapatkan kesimpulan-kesimpulan sebagai berikut:

1. Fuzzy Integer Programming (FIP) telah berhasil diterapkan sebagai algoritma untuk melakukan optimasi kandungan gizi menu harian. Penerapan ini membutuhkan data kandungan gizi bahan makanan, data satuan bahan makanan, serta data menu. Daftar menu harian yang akan dioptimasi terlebih dahulu diubah ke dalam model FIP. Model ini kemudian dikonversi ke model Integer Programming dengan metode konversi FIP ke MOIPP. Model hasil konversi ini kemudian diselesaikan dengan Integer Programming.

2. Penerapan Fuzzy Integer Programming untuk optimasi kandungan gizi menu harian menghasilkan solusi dengan tingkat optimalitas $100 \%$. Algoritma dapat memberikan solusi dengan rata-rata pemenuhan nutrisi di atas $100 \%$ dan dengan rata-rata penggunaan anggaran $46.59 \%$ hingga $66.74 \%$ dari anggaran yang ditentukan. Dengan demikian, dapat dikatakan bahwa solusi-solusi yang diberikan algoritma memiliki harga yang terjangkau dan memiliki nilai gizi yang mencukupi.

\section{SARAN}

Berikut adalah beberapa saran yang dapat digunakan sebagai landasan pengembangan penelitian lebih lanjut: 
8 Jurnal Teknologi Informasi dan Ilmu Komputer (JTIIK), Vol. 3, No. 2, Juni 2016, hlm. x-y

1. Metode dalam penelitian ini dapat dikembangkan sehingga dapat diterapkan untuk orang-orang dengan diet khusus.

2. Data kandungan gizi bahan makanan serta data batasan-batasan nutrisi, jika telah tersedia, sebaiknya menggunakan data yang dikeluarkan oleh lembaga di Indonesia.

3. Diperlukan suatu data yang menjelaskan mengenai faktor penyusutan suatu bahan sehingga kandungan nutrisi suatu menu dapat dihitung secara lebih tepat.

4. Diperlukan suatu data atau formula yang menjelaskan interaksi antar nutrien serta prioritas masing-masing nutrien, terutama jika diterapkan pada orang-orang dengan diet khusus.

\section{UCAPAN TERIMA KASIH}

Terima kasih kepada dosen Program Studi Ilmu Gizi Fakultas Kedokteran Universitas Brawijaya, Ibu Titis Sari Kusuma atas bantuannya dalam hal pengumpulan dan validasi data. Terima kasih pula atas saran dan masukan-masukan yang diberikan.

\section{DAFTAR PUSTAKA}

Bosch, Robert dan Trick, Michael. 2014. Integer Programming

Dash, R. B. \& Dash, P. D. P., 2012. Solving Fuzzy Integer Programming Problem as Multiobjective Integer Programming Problem. International Journal of Fuzzy Mathematics and Systems, Volume 2, pp. 307-314.

Fullér, R., 1991. On product-sum of triangular fuzzy numbers. Fuzzy Sets and Systems, 41(1), pp. 83-87.

Joshi, A. V., 2008. Extension of Support Vector Machines for Imprecise Data Using Fuzzy Set Theory. [e-book]. ProQuest. Tersedia melalui: Google Books <https://books.google.com> [Diakses 22 April 2016].

Karyadi, D. \& Muhilal, 1985. Kecukupan gizi yang dianjurkan. Jakarta: Gramedia.

Oruç, K. O. et al., 2012. Menu Planning with Fuzzy 0-1 Integer Programming. 3rd International Symposium on Sustainable Development.

Prasetyo, G. A., 2010. Aplikasi Fuzzy Linear Programming untuk Meminimalkan Biaya Pemenuhan Kebutuhan Gizi. S1. Universitas Brawijaya.

Roseline, S. S. \& Amirtharaj, E. H., 2012. Different strategies to solve fuzzy linear programming problems. Recent Research in Science and Technology, 4(5), pp. 10-14.

U.S. Department of Agriculture, A. R. S., 2014.
USDA National Nutrient Database for Standard Reference, Release 28. [basis data] Tersedia di: $<$ http://ndb.nal.usda.gov/ndb/> [Diakses 21 April 2016]. 